\title{
Erratum to: Of Intake and Outcomes: Wage Trajectories of Immigrant Classes in Canada
}

\author{
Fernando Mata $^{1} \cdot$ Ravi Pendakur ${ }^{2}$
}

Published online: 15 September 2016

(C) Springer Science+Business Media Dordrecht 2016

\section{Erratum to: Int. Migration \& Integration DOI 10.1007/s12134-016-0501-1}

The name of one of the authors was unfortunately misspelled as "Ferando Mata" when it should be "Fernando Mata". However, it has been addressed and is not anymore present in the published copies of the article.

The online version of the original article can be found at http://dx.doi.org/10.1007/s12134-016-0501-1.

\section{Ravi Pendakur}

pendakur@uottawa.ca

1 School of Sociological and Anthropological Studies, University of Ottawa, Ottawa, Ontario K1N $6 \mathrm{~N} 5$, Canada

2 Graduate School of Public and International Affairs, University of Ottawa, Ottawa, Ontario K1N 6N5, Canada 